\title{
Down the Up Staircase
}

\author{
Alford A. Young, Jr. ${ }^{1}$
}

Down the Up Staircase: Three Generations of a Harlem Family by Bruce D. Haynes and Syma Solovitch. New York: Columbia University Press, 2017.

I first met Bruce D. Haynes more than 20 years ago. We were at the beginning our professional careers (in fact, I was still writing my dissertation) and connected as two of the younger scholars participating in a series of meetings for New England-based sociologists interested in contemporary social theory. In one of these meetings he told me about his selling of his childhood home in Harlem to the hip-hop pioneer Fab 5 Freddy. I was born and raised in East Harlem and fully cognizant of the role that Freddy played in the local (and thereafter national) hiphop scene. As such, I found that story interesting in ways that many sociologists would not. (For the uninformed, after becoming long-established in New York City, Freddy was the original host of MTV's first hip-hop program, Yo! MTV Raps.) I already knew that Bruce was the grandson of a vanguard African American sociologist, George Edmund Haynes. Thus, after he told me about the sale, I figured that I had learned the most interesting things to ever know about him. After completing Down the Up Staircase: Three Generations of a Harlem Family, I realized that this was not the case.

As told through the voice of Haynes, the extraordinarily well-written, always insightful, and occasionally humorous Down the Up Staircase tells the story of the Haynes family from grandfather to grandsons. George Edmund Haynes was one of the first African Americans to receive a PhD in sociology (from Columbia University in 1912), and he was one of the most prolific scholars of his time. As argued quite effectively in this book, his great achievements as a member of the first wave of African American sociologists were masked by a greater historical neglect. While saying much about his grandfather's achievements and ultimate dismissal from this historic record, however, this work does not rest on the sole effort to tell the story of an important figure. Instead, through a memoir-style commentary, it aspires to tell the story of black life in Harlem throughout the twentieth century.

Doing so extends it far beyond a focus on the prominent sociologist who was an activist and associate of W. E. B. Du Bois and other turn-of-the-century race leaders to also consider the son of that figure - a man who, in his eyes and the eyes

\footnotetext{
1 Department of Sociology, University of Michigan, Room 3115 LSA Building, 500 S. State Street, Ann Arbor, Michigan, 48109-1382; e-mail: ayoun@umich.edu.
} 
of his spouse, never comes close to measuring up to the prominence of his fatherand that son's three sons. One of them, the sociologist who is coauthor of the book, together with his two brothers and their parents, experience lives consisting of extraordinarily eventful and dramatic twists and turns. What transpired over nearly 100 years of this family's history leaves the reader at various points shocked, disappointed, frustrated, empathetic, and amused. Remarkably, in the midst of these reactions the reader also gains valuable sociological insight into race, mobility, and urban living for African Americans.

Down the Up Staircase is not a story of black folks who live privileged lives amid a community of many black people who do not. Instead, it is an account of how a family encounters shifting degrees of status as it experiences economic challenges and confronts various family secrets that emerge over the course of time (this occurring even as Haynes's mother always remained well-coifed and always adorned with its material accoutrements while in public). Inclusive here are stories of cross-racial interaction in elite educational institutions, intra-racial class conflicts in urban public schools, and both in various kinds of workplaces. Aside from schools and workplaces, these encounters unfold for different family members in high-end department stores in downtown Manhattan, shady social gatherings in Times Square, and illicit after-hour clubs in Harlem. These accounts deliver very complicated and compelling depictions of how black and white lives become intertwined in New York City.

A captivating dimension of this work rests in how Bruce Haynes and his family effectively serve as objects of analysis for making sense of the complexity of African American life in Harlem throughout the twentieth century. Down the Up Staircase moves beyond reporting on how a family struggles with early prominence that goes unrecognized in later years to inform about the race- and class-specific conditions and circumstances pertaining to intergenerational mobility in twentieth-century America. In doing so, the work is not a sociological analysis in the conventional sense. It is, quite deliberately, a work that reports on how a family strove to embrace success across three generations while encountering racism, classism, mental health challenges, narcotics abuse, murder, infidelity, and much else that has come into black life in urban America throughout the twentieth century. In pulling all of this together, Haynes and Solovitch produce a story about the urban African American family experience even if only empirically focused on a single family.

As evident by the title, this is also very much a New York story. References to public interaction on 125th Street, the anticipation and ultimate arrival of cable television in Harlem, and the navigation of what are at certain points in time quite rigid - and at others very fluid - social boundaries between black and white neighborhoods and neighbors in and around Harlem may not speak precisely to the urban experiences of African American in other cities. Black Harlemites, however, may feel as though they are reading about the kind of family that once upon a time lived on their block. More importantly, this kind of parochialism allows for intensive focus on the myriad complexities and subtleties in a family's experience that calls into question any simple depiction of twentieth-century black family life as a process of linear upward or downward movement over time. In fact, the moral of the story is that the quest for mobility, even stability, involves complications and 
contradictions that do not effectively surface in many traditional scholarly analyses of the African American experience in the twentieth century.

This being the case, Down the Up Staircase delivers a strong sociological lesson that calls for new thinking about African Americans and the quest for mobility. Indeed, the final words of the book are among its most powerful in making that case. As the authors put it:

This book is a tribute to that family, which was never as carefree as the image we fashion for the world, never as secure in our futures, each generation walking a tightrope, one misstep from freefall. (p. 176)

Every sociologist - indeed everyone - interested in race, mobility, and the African American experience should read this book. It will motivate rethinking of the stakes and consequences for African Americans striving to get or stay ahead. For sociologists and other scholars of race and the urban experience, as well as lay readers who desire to understand more fully much of what black family life in urban America was all about during the past 100 years, it should be a required text.

\title{
Youth Street Gangs
}

\author{
Louis Kontos ${ }^{1}$
}

Youth Street Gangs: A Critical Appraisal. David C. Brotherton. New York: Routledge, 2015.

Over the last three decades, societal responses to the street gang problem have shifted from a mixture of social welfare and juvenile justice to militarized policing and draconian laws that ensure lifelong entanglement with the criminal system for a substantial part of the youth population. Even the idea that American street gangs are composed of the youth of American society, rather than foreign or public enemies, appears controversial against the backdrop of currently popular constructions and representations of the gang problem, and of the new wisdom in public policy. The stream of images and commentary that serves to pathologize and demonize street gangs lacks balance and resistance. For this reason alone, Brotherton's latest book deserves a serious reading.

A good part of this book reviews the academic literature about gangs in a historical context. The important question for Brotherton is not whether bond, subcultural, anomie, or learning theories can best explain gangs, because each of them can be supported through selected observation. Rather, the question is what is at stake by adopting a particular kind of theoretical language and focus. Why was labeling theory heralded in the 1960s and dropped in the late 1980s? Why was bond theory

\footnotetext{
1 John Jay College of Criminal Justice, CUNY, New York, New York; e-mail: 1kontos@jjay.cuny.edu.
} 